\title{
Effect of settling time and pH on the treatment of domes- tic grey water using custard apple seeds as natural coag- ulant
}

\author{
Rathore Kavish ${ }^{1}$, Nautiyal Roopika ${ }^{2}$, Raj Ishant ${ }^{3}$, Uliana Shivangi ${ }^{4}$, Shah Brij ${ }^{5}$, T. S. Anantha \\ Singh $6^{*}$
}

1, 2, 3, 4, 5, 6 Pandit Deendayal Petroleum University, Gandhinagar, India

\section{Keywords \\ Grey water \\ Natural coagulant \\ Custard apple \\ Optimum dosage \\ Removal efficiency}

Received: 2 November 2017

Accepted: 18 January 2018

Published: 7 February 2018

\begin{abstract}
The main objective of the present study is to investigate the effect of natural coagulants (selected seed) on the treatment of domestic grey water and to study the factors affecting the removal efficiency in terms of Turbidity and COD removal. Effect of settling time and $\mathrm{pH}$ variation on the removal efficiency was also studied. Grey water is all wastewater generated in households, public or commercial properties without fecal contamination. Treating and reusing grey water decreases the quantity of fresh water needed and lessens the wastewater flow flowing into the sewer system. The grey water sample was taken from a residential society in Ahmedabad and the natural coagulant used was freely and locally available Custard Apple (Annona Reticulata) seeds. The initial characteristics of the grey water were accessed based on the parameters $\mathrm{pH}$, TS, TDS, Turbidity, and COD and measured as 7.79, 780 $\mathrm{mg} / \mathrm{L}, 590 \mathrm{mg} / \mathrm{L}, 276 \mathrm{NTU}$, and $625 \mathrm{mg} / \mathrm{L}$, respectively. Turbidity and COD were analyzed for different Coagulant Dosage concentrations and by varying the Settling Time and $\mathrm{pH}$. The settling time was varied from 10 to 30 minutes considering the elimination of micro-flocs, and $\mathrm{pH}$ was varied from 4 to 9 . The optimum results were obtained at a settling time of 30 minutes, $\mathrm{pH} 9$ and $10 \mathrm{mg} / \mathrm{L}$ coagulant dosage giving 85\% turbidity removal and 82\% COD removal. It was observed that adding organic coagulant beyond the optimum level contributes to COD. Water scarcity along with climate change, population growth, and development, pose difficulties for the present water supply systems. Today, 2.1 billion people globally are living without a safe water supply near their homes. Hence, domestic wastewater treatment along with its reuse is becoming a significant topic for research.
\end{abstract}

(C) 2018 The Author(s). Published by TAF Publishing.

\section{INTRODUCTION}

Water is the utmost vital and abundant compounds of the environment as all living beings require it for their evolution and existence. Safe and freely accessible water is essential for civic well-being, whether it is used for drinking, domestic use or leisure activities. On 28 July 2010, the UN General Assembly unambiguously acknowledged the human right to water and sanitation through Resolution 64/292 and accredited that potable water and hygiene are crucial to the recognition of all human rights. Everybody has the right to enough, continuous, harmless, acceptable, reachable and inexpensive water for personal and local use [1]. As shown in Infographic 1 , there are 2.1 billion people who are deprived of a clean water supply near their home, spending a lot of time queuing or trekking to distant sources and dealing with harmful health impacts of using polluted water. Poor hygiene and polluted water are directly related to the spread of diseases such as cholera, diarrhea, dysentery, hepatitis A, typhoid and polio. Various challenges for the water supply systems are posed by environment change, increase in water shortage; population growth and development. By $2025,50 \%$ of the global population would be living in water scarce areas $[2,3]$.

\footnotetext{
${ }^{*}$ Corresponding author: T. S. Anantha Singh

†email: singh87nitt@gmail.com
} 


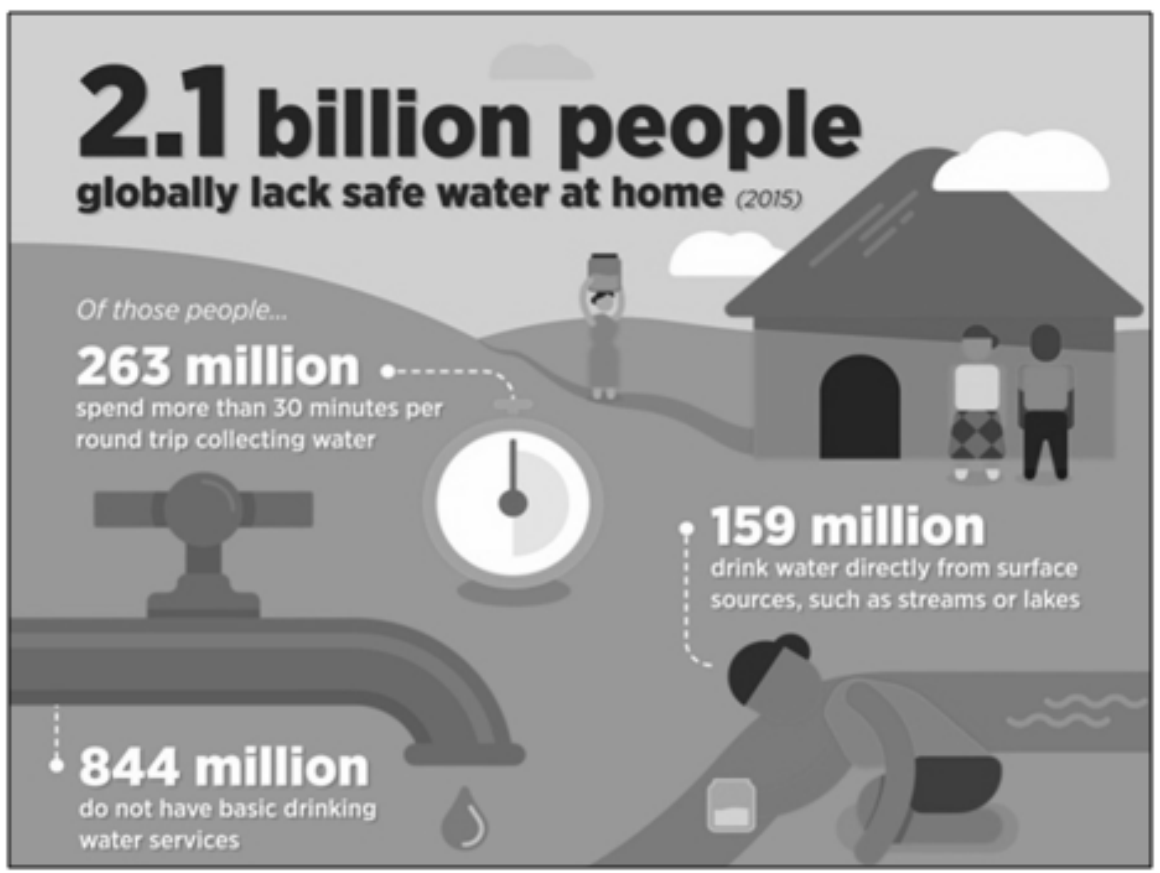

Fig. 1. Global population lacking safe water at home [3]

Increasing water scarcity and inadequate sanitation led the researchers across the globe, to focus on the domestic wastewater treatment along with its reuse [4, 5]. In urban regions, the current and future water demands are addressed by two approaches. The first approach includes developing additional local natural supplies such as reservoirs and dams, rainwater harvesting, sea water desalination, getting water from large distances and deep groundwater abstraction [6]. In several cases, these added sources are either inaccessible or can be established only at enormously high direct and indirect costs when compared to the exist- ing water sources. The next approach is to lessen the fresh water demands by: (i) improving the present water supply system by reducing leak, mounting water-saving equipment and by altering community behavior; (ii) wastewater treatment and reutilizing [7].

Wastewater includes water coming from hand basins, showers, toilets, kitchen sinks, dish washers etc. Grey water can be defined as wastewater without streams from toilets [8]. Grey water is all wastewater without fecal contamination. Sources of grey water along with their constituents are presented in Figure 1.

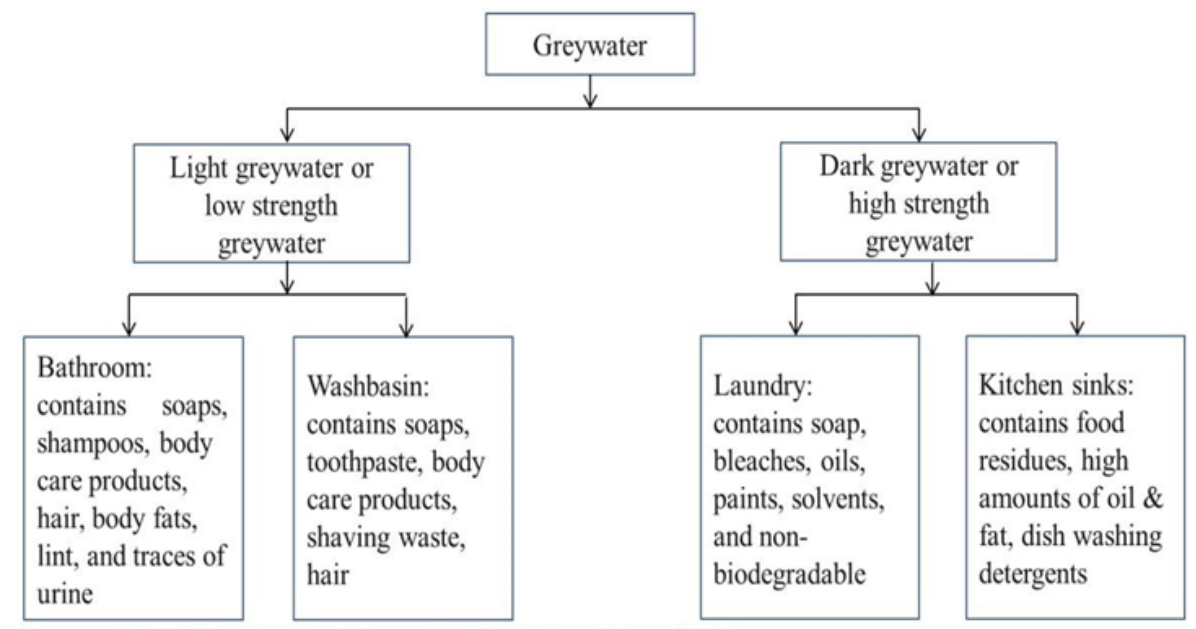

Fig. 2. Grey water sources and their constituents $[9,10,11]$ 
These days, the ordinary unified water administration approach is becoming less appropriate on account of its high speculation cost for long sewerage lines, which is now and then significantly higher than treatment facilities, high operation and maintenance costs, high quantity of good quality water required for transportation to long distances and other high dangers included. On the other hand due to the decentralized approach, onsite segregation-collectiontreatment-reuse of grey water for residential areas is the need of the hour [12].

Grey water, which constitutes of more than $70 \%$ of total domestic water intake, has fewer pathogens and also has much lesser quantity of carbon-based compounds as compared to household wastewater [13]. Treatment and reuse of grey water mainly aid the following purposes: it lessens the quantity of fresh water required to supply to a home and also lessens the quantity of wastewater flowing into the sewer or septic systems. Properly treated grey water can be possibly re-used for ornamental irrigation, toilet flushing and several other types of cleaning works. Such reuse improves water usage proficiency and can play a vital role in forthcoming water management policies.

Inorganic coagulants which are presently used are Alum (Aluminum Sulfate), Ferric Chloride, Polyaluminum Chloride (PACl) \& Aluminum-Chloro-hydrate (ACH). Various disadvantages associated with inorganic coagulants are: these coagulants are not always available at a reasonable price, can leave undesirable large volumes of non-biodegradable sludge, are particularly effective on raw water with low turbidity and also have serious effects on human body like Alzheimer's disease. Keeping in mind these drawbacks, it is necessary to find an alternative which is environment friendly and make use of cheaper coagulants.

Variety of effective natural coagulants from plant origin has been recognized: Nirmali [14]; Okra [15]; Moringa oleifera [16] and Manilkara Zapota [17]. By using natural coagulants, necessary quantity of coagulant will be reduced and also the associated costs as higher coagulant efficiency of natural coagulants allows more active colloidal aggregation and more consistent floc than with synthetic reagents.

Annona Reticulata commonly known as Custard Apple is naturally and locally available seed that can be used as a potential coagulant. Custard Apple consists of 9.7\% moisture, $10 \%$ carbohydrate, $17 \%$ protein, $29 \%$ fat and $32 \%$ fibre [18]. Custard Apple has other benefits like insect repellant, bio gas production and pharmaceutical usage.

\section{A. Objective of the Study}

The main objective of the present study is to investigate the effect of natural coagulants (selected seed) on the treatment of domestic grey water and to study the factors affecting the removal efficiency in terms of Turbidity and COD removal. Effect of settling time and $\mathrm{pH}$ variation on the removal efficiency was also studied.

\section{MATERIALS AND METHODOLOGY}

\section{A. Grey water collection and Natural coagulant used}

The grey water which was used for this study was taken from a residential society in Ahmedabad, India. The initial characteristics of grey water were done as per IS: 3025 and are presented in Table 1. The natural coagulant used was raw Custard Apple seeds which were freely and locally available in the region.

\section{B. Preparation of Custard Apple Seed Extract}

Custard Apple seeds were obtained from different places in Ahmedabad. High quality seeds were selected. They were fresh and disease free. These seeds were de-shelled and dried in sunlight for at least 10 hours. The kernel part of the seed was crushed and grounded into a fine powder by using a domestic blender. This fine powder was then stored in container until further usage. The extract was prepared by taking $2 \mathrm{~g}$ of finely crushed seed and mixing with distilled water. The suspension obtained was then stirred using a magnetic stirrer for 30 minutes for the purpose of homogeneous mixing and extraction of coagulant. The extract was then stored in the refrigerator.

TABLE 1

CHARACTERISTICS OF GREY WATER USED FOR THE STUDY

\begin{tabular}{lc}
\hline \hline Parameter & Initial investigation \\
\hline $\mathrm{pH}$ & 7.79 \\
$\mathrm{TS}(\mathrm{mg} / \mathrm{L})$ & 780 \\
$\mathrm{TDS}(\mathrm{mg} / \mathrm{L})$ & 590 \\
COD $(\mathrm{mg} / \mathrm{L})$ & 625 \\
Turbidity (NTU) & 276 \\
\hline \hline
\end{tabular}




\section{Experimental Study}

Was taken in a 1 litre beaker with a working volume of 500 $\mathrm{mL}$. The concentration of Custard Apple seed extract was varied from $3 \mathrm{mg} / \mathrm{L}$ to $50 \mathrm{mg} / \mathrm{L}$. Beaker was kept in the flocculator and rotating spindles were inserted till the depth of two-third of the beaker. Flocculation was carried out in two steps. First, the rotating spindles were set at the speed of $120 \mathrm{rpm}$ for 2 minutes and then the speed was reduced to $20 \mathrm{rpm}$ for 10 minutes. The settling time was varied from 10 to 30 minutes and $\mathrm{pH}$ was varied from 4 to 9 . Turbidity and COD were analyzed as per IS: 3025 .

\section{RESULTS AND DISCUSSION}

\section{A. Effect of Coagulant Dosage Variation}

To investigate the effect of coagulant dosage on the removal efficiency of grey water, the custard apple seed concentration has been varied from $3 \mathrm{mg} / \mathrm{L}$ to $50 \mathrm{mg} / \mathrm{L}$. The initial concentration of the grey water was maintained as pH 7.79, turbidity $276 \mathrm{NTU}$ and COD as $625 \mathrm{mg} / \mathrm{L}$. It can be observed from the Figure 2, the increase in coagulant dosage increases the removal efficiency of Turbidity and COD from the grey water, up to a certain level. The optimum removal was observed at $10 \mathrm{mg} / \mathrm{L}$ of coagulant dosage. It was also observed that the organic coagulant beyond the optimum level contributes to the COD. When the dosage was increased from $3 \mathrm{mg} / \mathrm{L}$ to $10 \mathrm{mg} / \mathrm{L}$, the COD removal efficiency increases from 67 to $72 \%$ and on further increase in the coagulant dosage the removal efficiency decreases.
Mucilage in cactus consists of carbohydrates like larabinose, l-rhamnose, d-xylose, thiamine, galacturonic acid, nicotinic acid and leucine which accounts for its high removal efficiency, as established by Saenz et al., 2001. Custard apple seed contain significant amounts of active compounds such as alkaloids, cyclohexapeptides, and acetogenins and trivial amount of Carotene, Thiamine, Riboflavin, Niacin, Ascorbic Acid, and Nicotinic Acid that carries an overall positive charge in the solution. These proteins act similar to the man-made, positively charged polymer coagulants. On adding these proteins to raw water, they bind primarily to the negatively charged particulates which are responsible for turbidity in raw water in the form of silt, clay, bacteria etc. On uniform mixing, these attached particulates grow in size forming flocs. After allowing the mixture to settle for an appropriate time, flocs get settled by gravity and can be removed by filtration.

Custard apple seeds can be used as coagulating agent as they contain proteins and carbohydrates that have proved to be effective in the treatment of grey water. Further, the Figure 3 clearly demonstrates that the increase in coagulant dosage beyond the optimal level contributes to the COD. This may be because of the uncoagulated organic custard apple seed coagulant. These can be evident from the turbidity removal figure. The effect of settling time variation with respect to different coagulant dosage on Turbidity and COD can be seen in Table 2 .

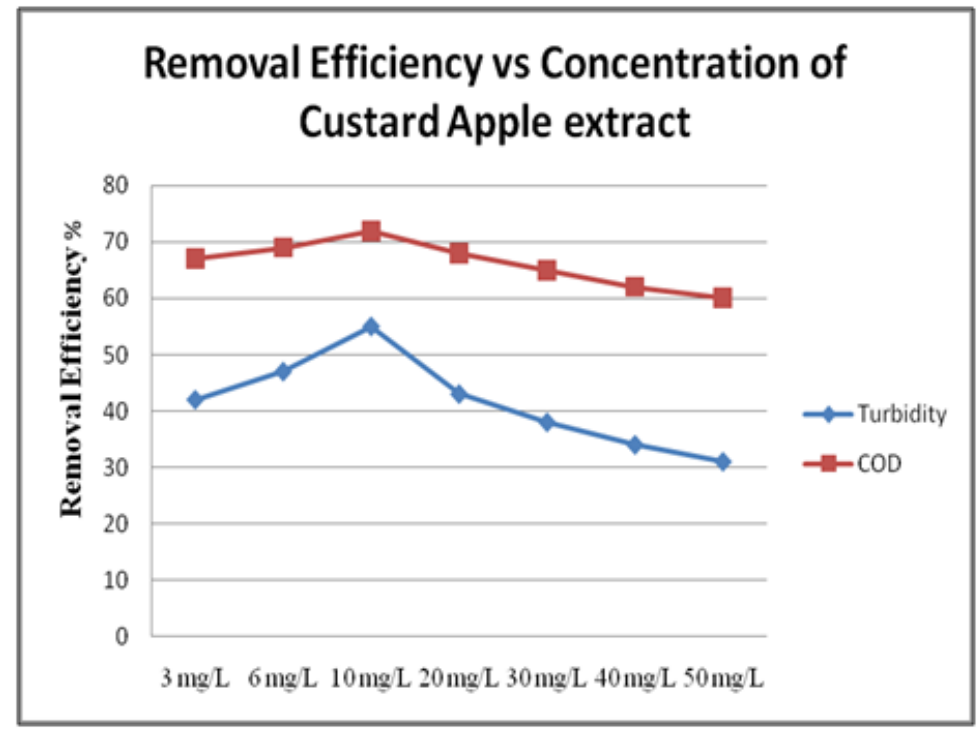

Fig. 3. Effect of coagulant concentration variation (30 min Settling time) 


\section{B. Effect of pH Variation}

pH is an important factor which affects the coagulation process. The three different $\mathrm{pH}$ ranges considered for the study were $\mathrm{pH} 4,6$ and 9. The effect of $\mathrm{pH}$ variation on Turbidity and COD is given in Table 2. For different values of $\mathrm{pH}$, removal efficiency of turbidity and COD was observed. As the $\mathrm{pH}$ increases, the removal efficiency of turbidity and COD increases. Figure 5 shows the removal efficiency obtained by varying the $\mathrm{pH}$. Figure 3 represents the effect of $\mathrm{pH}$ variation on turbidity removal. From the graph, it can be seen that for maximum settling time and maximum value of $\mathrm{pH}$, turbidity is minimum. Figure 4 shows the effect of $\mathrm{pH}$ variation on COD removal. For optimum dosage, COD was minimum for maximum settling time of 30 minutes and maximum $\mathrm{pH}$ of 9. Within the considered range of $\mathrm{pH}$ the removal efficiency got increased with the increase in $\mathrm{pH}$. When the $\mathrm{pH}$ was increased from 4 to 9 , the turbidity and COD decreased from 139 to $43 \mathrm{NTU}$ and 252 to $115 \mathrm{mg} / \mathrm{L}$ respectively. This indicated that the more active coagulant components generation occurs in the near alkaline $\mathrm{pH}$ rather than the near acidic $\mathrm{pH}$.

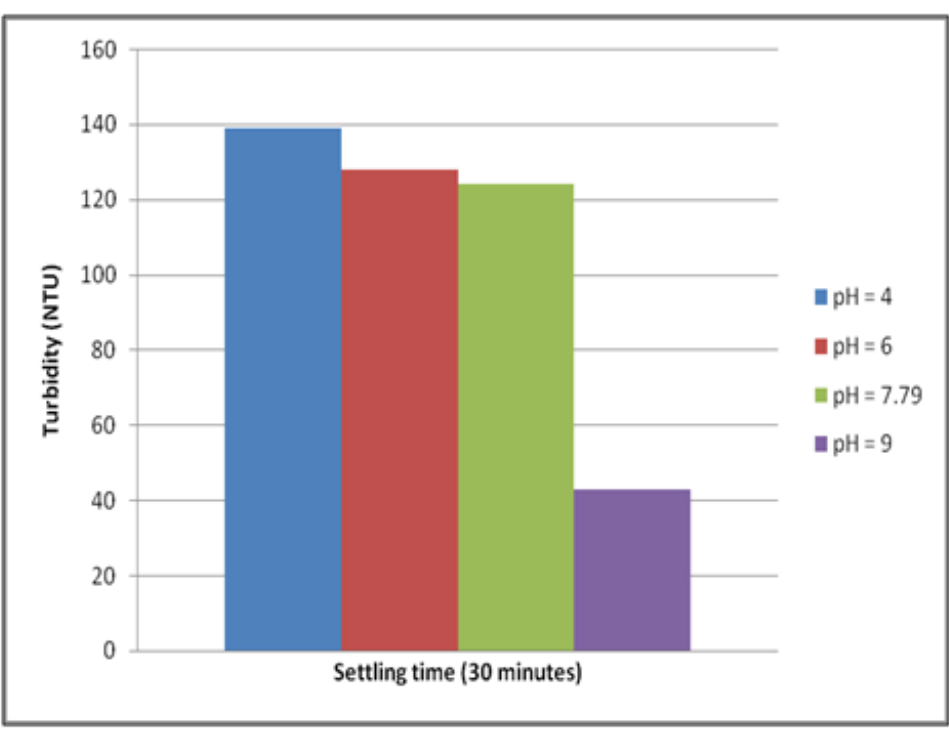

Fig. 4. Effect of $\mathrm{pH}$ variation on Turbidity removal

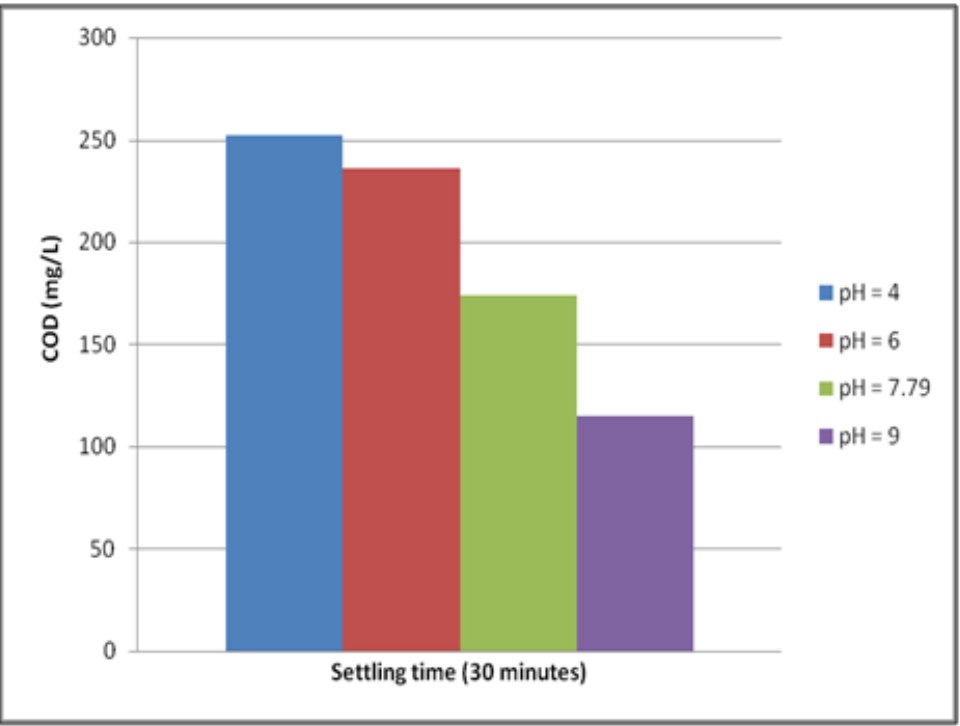

Fig. 5. Effect of $\mathrm{pH}$ Variation on COD removal 


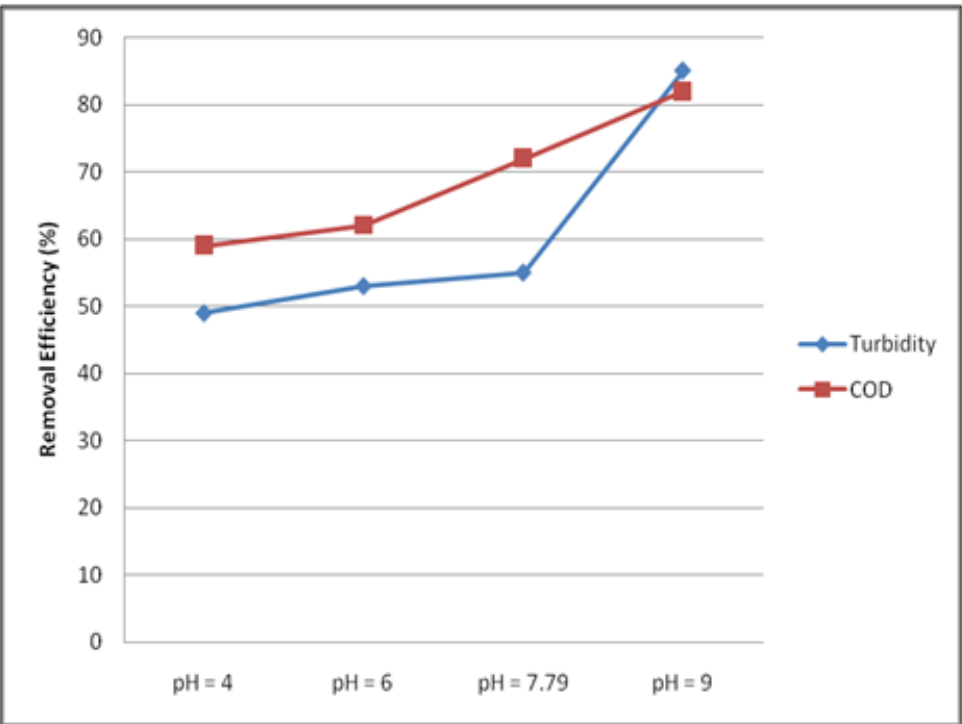

Fig. 6. Removal efficiency obtained by varying pH $(10 \mathrm{mg} / \mathrm{L}$ coagulant dosage)

TABLE 2

EFFECT OF VARIATION IN PH ON TURBIDITY AND COD AT OPTIMUM DOSAGE 10MG/L

\begin{tabular}{lllllll}
\hline \hline Settling time (min) & $\mathrm{pH}=4$ & & $\mathrm{pH}=6$ & \multicolumn{3}{c}{$\mathrm{pH}=9$} \\
\cline { 2 - 7 } & $\begin{array}{l}\text { Turbidity } \\
\text { (NTU) }\end{array}$ & $\begin{array}{l}\text { COD } \\
(\mathrm{mg} / \mathrm{L})\end{array}$ & $\begin{array}{l}\text { Turbidity } \\
(\mathrm{NTU})\end{array}$ & $\begin{array}{l}\text { COD } \\
(\mathrm{mg} / \mathrm{L})\end{array}$ & $\begin{array}{l}\text { Turbidity } \\
(\mathrm{NTU})\end{array}$ & $\begin{array}{l}\text { COD } \\
(\mathrm{mg} / \mathrm{L})\end{array}$ \\
\hline 30 & 139 & 252 & 128 & 236 & 43 & 115 \\
\hline \hline
\end{tabular}

\section{Effect of Settling Time Variation}

To study the effect of floc settling with respect to the time, the sedimentation/settling time was varied from $10 \mathrm{~min}$ to $30 \mathrm{~min}$ for different conditions. Settling time refers to time given to settle down suspended particles. Table 3 shows the effect of settling time on the removal of turbidity and COD from grey water. Different concentrations of custard apple seeds were taken and their turbidity removal was studied for different settling time. The maximum removal of COD and turbidity can be seen for an optimum dosage of $10 \mathrm{mg} / \mathrm{L}$ and settling time of 30 minutes. This phenomenon can be explained as for maximum settling time maximum solid particles would settle which leads to maximum removal of turbidity. Figure 8 shows the removal efficiency obtained by varying the settling time. Figure 6 represents effect of settling time variation on turbidity removal and Figure 7 represents the effect of settling time variation on COD removal. From the graph, it is observed that for maximum coagulant concentration of $50 \mathrm{mg} / \mathrm{L}$, COD was maximum whereas for optimum dosage of $10 \mathrm{mg} / \mathrm{L}$, COD was minimum.

TABLE 3

EFFECT OF VARIATION IN SETTLING TIME ON TURBIDITY AND COD

\begin{tabular}{|c|c|c|c|c|}
\hline \multirow{3}{*}{$\begin{array}{l}\text { Concentration of } \\
\text { Custard Apple } \\
\text { Extract (mg/L) }\end{array}$} & \multicolumn{3}{|c|}{ Turbidity after settling time of: (NTU) } & \multirow{3}{*}{$\begin{array}{l}\text { COD after settling } \\
\text { time of: }(\mathrm{mg} / \mathrm{l}) \\
30 \mathrm{~min}\end{array}$} \\
\hline & $10 \mathrm{~min}$ & $20 \min$ & $30 \mathrm{~min}$ & \\
\hline & & & & \\
\hline 3 & 185 & 171 & 158 & 202 \\
\hline 6 & 183 & 160 & 147 & 189 \\
\hline 10 & 183 & 164 & 124 & 174 \\
\hline 20 & 184 & 172 & 156 & 193 \\
\hline 30 & 185 & 180 & 171 & 215 \\
\hline 40 & 188 & 181 & 181 & 237 \\
\hline 50 & 195 & 190 & 190 & 249 \\
\hline
\end{tabular}




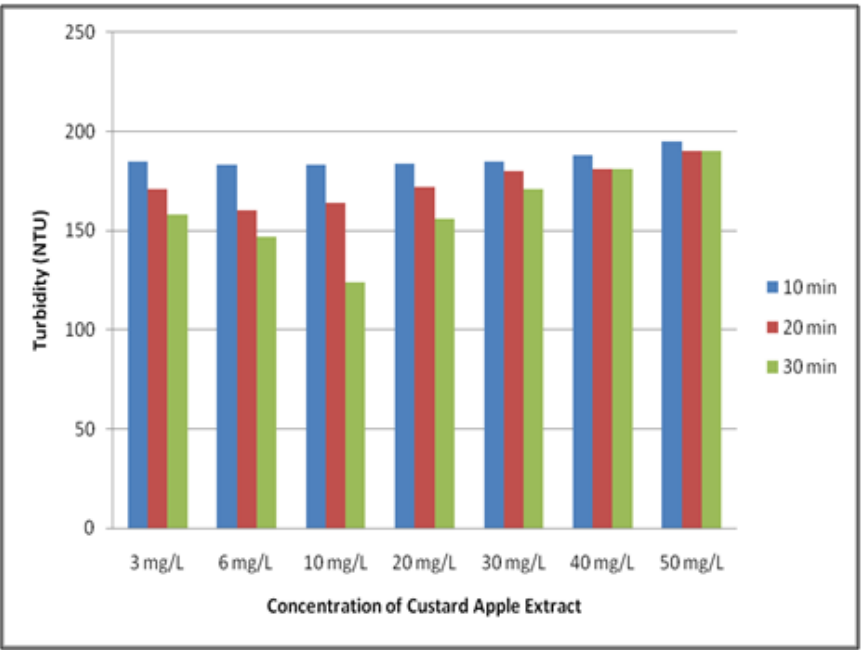

Fig. 7. Effect of settling time variation on Turbidity removal

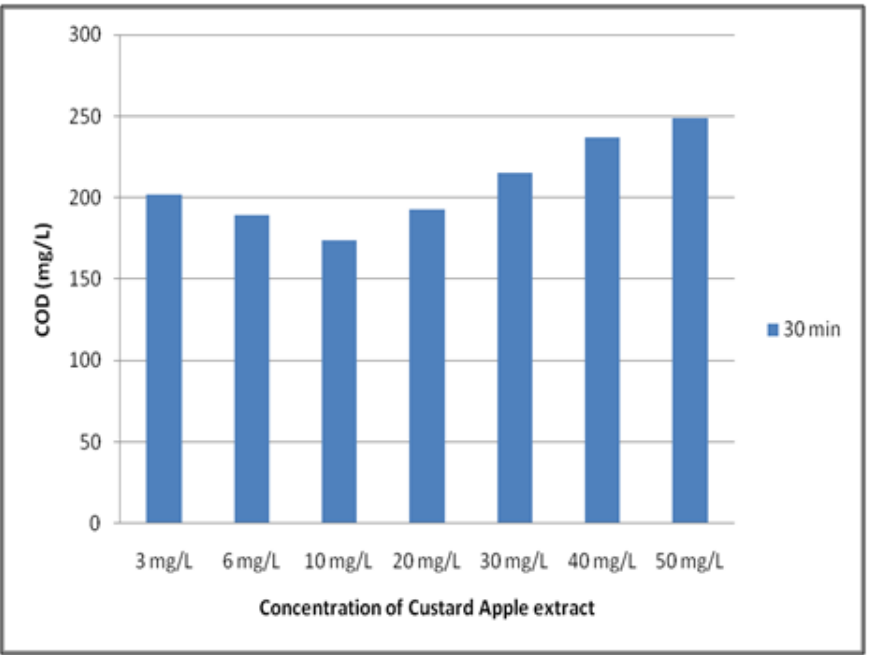

Fig. 8. Effect of settling time variation on COD removal

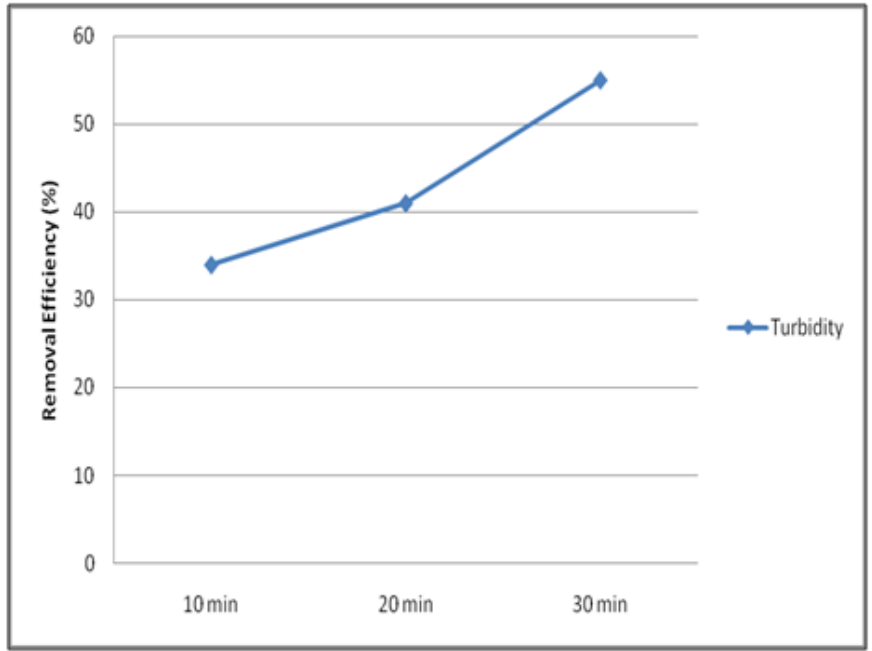

Fig. 9. Removal efficiency obtained by varying settling time (10 mg/L coagulant dosage) 


\section{CONCLUSION}

The optimum dosage of Custard Apple Seeds coagulant was found to be $10 \mathrm{mg} / \mathrm{l}$. The maximum removal efficiency of turbidity and COD was observed at $\mathrm{pH} 9$ and 30 min of settling time. At optimum conditions, $85 \%$ turbidity and $82 \%$ COD removal was observed. Turbidity and COD were found to be decreased at higher $\mathrm{pH}$ values. The Custard apple seed can be used as an alternative natural coagulant for the treatment of grey water. The study concluded that in the treatment of grey water using custard apple seed as natural coagulant, the effect of settling time variation is not significant while $\mathrm{pH}$ variation greatly affected the removal efficiency.

\section{REFERENCES}

[1] P. Solon, "The human right to water and sanitation," 2010. [Online]. Available: https://goo.gl/y8cWAF

[2] P. Roya, R. Hadi, A. Hossein, and M. Vahedian, "Survey of wastewater stabilization pond potential in meeting environmental standards," International Journal of Applied and Physical Sciences, vol. 1, no. 1, pp. 19-21, 2015. doi: 10.20469/ijaps.50003

[3] World Health Organization, "Fact sheet about progress on drinking-water, sanitation and hygiene," 2017. [Online]. Available: https://goo.gl/Ygq4fh

[4] K. A. M. Abdel, "Studying the efficiency of grey water treatment by using rotating biological contactors system," Journal of King Saud University-Engineering Sciences, vol. 25, no. 2, pp. 89-95, 2013. doi: 10.1016/j.jksues.2012.05.003

[5] A. Panrare, T. Tondee and P. Sohsalam, "Effect of plant density in constructed wetland on domestic wastewater treating efficiency," International Journal of Applied and Physical Sciences, vol. 2, no. 1, pp. 7-12, 2016. doi: 10.1016/j.jksues. 2012.05.003

[6] S. S. Surendran, "The development of an in house greywater and roof water reclamation system for large institutions during 1994 to 1998," Ph.D. dissertation, Department of Civil and Building Engineering, Loughborough University, Loughborough, UK, 2001.

[7] D. Hunt, D. Lombardi, and I. Jefferson, "Sustainable water? A feasibility study for Birmingham Eastside," in Proceedings of $4^{\text {th }}$ Chartered Institution of Water and Environmental Management Annual Conference, Newcastle, UK, 2006.

[8] B. Jefferson, A. Laine, S. Parsons, T. Stephenson, and S. Judd, "Technologies for domestic wastewater recycling," Urban water, vol. 1, no. 4, pp. 285-292, 2000. doi: 10.1016/s1462-0758(00)00030-3

[9] D. M. Ghaitidak and K. D. Yadav, "Characteristics and treatment of greywater: A review," Environmental Science and Pollution Research, vol. 20, no. 5, pp. 2795-2809, 2013. doi: 10.1007/s11356-013-1533-0

[10] M. Noah, “Graywater use still a gray area," Journal of environmental health, vol. 64, no. 10, pp. 22-35, 2002. doi: 10. $2307 / 3431911$

[11] A. Morel et al., Greywater Management in Low and Middle-Income Countries. Dubendorf, Switzerland: Swiss Federal Institute of Aquatic Science and Technology, 2006.

[12] R. Otterpohl, A. Albold, and M. Oldenburg, "Source control in urban sanitation and waste management: Ten systems with reuse of resources," Water Science and Technology, vol. 39, no. 5, pp. 153-160, 1999. doi: 10.2166/wst.1999.0234

[13] M. Henze, "Waste design for households with respect to water, organics and nutrients," Water Science and Technology, vol. 35, no. 9, pp. 113-120, 1997. doi: 10.2166/wst.1997.0335

[14] P. Tripathi, M. Chaudhuri, and S. Bokil, "Nirmali seed a naturally occurring coagulant," Indian Journal of Environmental Health, vol. 18, no. 4, pp. 14-50, 1976.

[15] A. A. Al-Samawi and E. M. Shokralla, "An investigation into an indigenous natural coagulant," Journal of Environmental Science \& Health Part A, vol. 31, no. 8, pp. 1881-1897, 1996. doi: 10.1080/10934529609376463

[16] S. A. A. Jahn, "Using moringa seeds as coagulants in developing countries," Journal-American Water Works Association, vol. 80, no. 6, pp. 43-50, 1988. doi: 10.1002/j.1551-8833.1988.tb03052.x

[17] R. Nautiyal, S. Uliana, I. Raj, B. Shah, K. Rathore, and A. Singh, "Decentralized treatment of grey water by natural coagulants in the presence of coagulation aid," in Conference on Civil, Structural, and Environmental Engineering, Ottawa, Canada.

[18] I. Amoo, A. Emenike, and V. Akpambang, "Compositional evaluation of annona cherimoya (custard apple) fruit," Trends in Applied Sciences Research, vol. 3, no. 2, pp. 216-220, 2008. doi: 10.3923/tasr.2008.216.220 